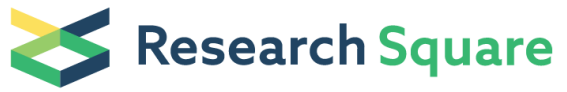 \\ Preprints are preliminary reports that have not undergone peer review. \\ They should not be considered conclusive, used to inform clinical practice, or referenced by the media as validated information.
}

\section{Predicting Outcomes of Abdominal Surgical Emergencies in the Elderly Population Using a CT Muscle Gauge}

\author{
Yu-San Tee \\ Chang Gung Memorial Hospital \\ Chi-Tung Cheng \\ Chang Gung Memorial Hospital \\ Yu-Tung Wu \\ Chiayi Chang Gung Memorial Hospital \\ Chih-Po Hsu \\ Chang Gung Memorial Hospital \\ Shih-Ching Kang \\ Chang Gung Memorial Hospital \\ Chi-Hsun Hsieh ( $\square$ hsieh0818@cgmh.org.tw) \\ Chang Gung Memorial Hospital Linkou Branch \\ Brian A. Derstine \\ University of Michigan Medical School \\ Grace L. Su \\ University of Michigan Medical School

\section{Stewart C. Wang} \\ University of Michigan Medical School \\ Chih-Yuan Fu \\ Chang Gung Memorial Hospital \\ Chien-Hung Liao \\ Chang Gung Memorial Hospital
}

\section{Research article}

Keywords: Muscle gauge, frailty, elderly, abdominal emergencies, surgical abdomen

Posted Date: August 7th, 2020

DOI: https://doi.org/10.21203/rs.3.rs-53267/v1

License: (c) (i) This work is licensed under a Creative Commons Attribution 4.0 International License. Read Full License

Version of Record: A version of this preprint was published at Aging Clinical and Experimental Research on April 5th, 2021. See the published version at https://doi.org/10.1007/s40520-020-01769-9. 


\section{Abstract}

Background. Frailty has been shown to be an independent negative predictor of surgical outcomes in geriatric patients. Traditional measurements of frailty are impractical in emergency settings, and computed tomography (CT)-measured skeletal muscle mass has been proposed as an alternative. However, the cutoff values of these CT metrics for frailty are still unknown, and their impact on abdominal emergencies in the elderly population is unclear.

Study Design: A total of 462 young trauma patients aged 18-40 years were analyzed to establish sex-specific reference cutoff values for the CT-measured muscle index (MI) and muscle gauge (MG) values. The impacts of low $\mathrm{MI}$ and MG values were investigated in 1192 elderly patients (aged $\geq 65$ years) undergoing abdominal surgery.

Results. The sex-specific cutoff values for MI and MG were determined by adopting European Working Group on Sarcopenia in Older People (EWGSOP) guidelines. The correlation between MG and ageing was significantly stronger than that between $\mathrm{Ml}$ and ageing. With regard to the MG, the $L 4$ psoas muscle gauge ( $L 4 P M G$ ) was further investigated in an elderly cohort owing to its high predictive value and ease of use in the clinical setting. A low L4 PMG value was an independent risk factor for overall complications and mortality in elderly patients with abdominal emergencies.

Conclusion: The current study was the largest study investigating the correlations between MG values and ageing in the Asian population. Frailty, as indicated by a low L4 PMG value, may help surgeons during preoperative decision making regarding geriatric patients with abdominal emergencies.

\section{Background}

Abdominal surgical emergencies in the elderly population are a potentially fatal condition that remains a challenge with regard to surgical decision making. Identifying preoperative risk factors is crucial for these patients. Several systems, such as the American Society of Anesthesiologists (ASA) classification system(1), Charlson Comorbidity Index (CCI)(2), and American College of Surgeons National Surgical Quality Improvement Program database (ACS NSQIP)(3), have been proposed for use during preoperative risk assessment. However, none of these systems provide the patient's preoperative functional status. Frailty, as an age-related risk factor, is rarely included in the assessment before an emergency operation(4). However, it has been associated with poor surgical outcomes in elderly patients and is increasingly used as a functional metric in perioperative risk assessments(5-8). Traditional assessment tools (measuring grip strength, establishing walking speed, and administering detailed multi-item questionnaires) that are used to evaluate frailty are usually unavailable in the emergency setting(9). Recent evidence suggests that frailty, as indicated by low values for skeletal muscle area, skeletal muscle index, and skeletal muscle density, can be used to predict surgical outcomes(10-13). Computed tomography (CT) images are often obtained in emergency settings to assist with preoperative diagnosis and advance surgical planning, and they can rapidly provide quantitative and qualitative measurements of skeletal muscle. However, there have been few studies discussing the changes in the CT-measured muscle metrics associated with aging in the healthy population, and clear cutoff values to define "low" muscle metrics are lacking $(14,15)$.

By describing the distribution of muscle index (MI) and muscle gauge (MG) values at different vertebral levels in the Asian trauma population, this study established the cutoff values of these CT metrics. In addition, we investigated their prognostic value in geriatric patients presenting with abdominal emergencies.

\section{Materials And Methods}

\section{Reference Cohort}

The reference cohort was described in a previous study(15). In summary, a total of 939 trauma patients with a mean age of 42.16 years (standard deviation, SD: 17.62) were included. CT imaging of cross-sectional areas of the skeletal muscle at the T12 and L3 vertebral levels, the dorsal muscle group at the T12 vertebral level, and the psoas muscle at the L4 vertebral level were measured. The muscle areas were normalized by the patient's height to obtain the muscle index $\left(\mathrm{Ml}, \mathrm{in} \mathrm{cm}^{2} / \mathrm{m}^{2}\right)(16)$. To further investigate the impact of both muscle quantity and muscle quality, a muscle gauge ( $\left.\mathrm{MG}, \mathrm{cm}^{2} \mathrm{HU} / \mathrm{m}^{2}\right)$ was used. It was first described by Weinberg et al., and it is calculated by multiplying the MI by the mean muscle density(17).

Muscle index $(\mathrm{MI})=$ cross-sectional muscle area $\left(\mathrm{cm}^{2}\right) /$ subject's heigh ${ }^{2}\left(\mathrm{~m}^{2}\right)$ 
Muscle gauge $(\mathrm{MG})=$ cross-sectional muscle area $\left(\mathrm{cm}^{2}\right) \times$ mean muscle density $(\mathrm{HU}) /$ subject's height $^{2}\left(\mathrm{~m}^{2}\right)$

\section{Study Cohort}

We retrospectively reviewed the medical records of geriatric patients (aged 65 years old) who presented with abdominal emergencies at a single medical center between September 2010 and December 2016. A total of 1907 patients over age 65 underwent emergency abdominal surgery at our institution. The exclusion criteria included unavailability of preoperative CT in the picture archiving and communication system (PACS) repository $(n=418)$, missing recorded body height $(n=254)$, and incomplete medical records $(n=48)$.

After exclusion, a total of 1192 patients ( 660 males, 532 females) were enrolled in the study. Clinical data were collected for the following variables: age, sex, height, weight, medical comorbidities, and vital signs at the emergency department. The MI and MG of the cohort were measured. Hemodynamic instability was defined as a systolic blood pressure less than $90 \mathrm{mmHg}$ during emergency admission.

The primary outcome measures in this analysis were perioperative complications and overall mortality. The secondary outcomes included were the length of hospital stay (LOS) and length of intensive care unit stay (ICU LOS).

\section{CT Image Processing}

The patients' preoperative CT studies were collected from the PACS repository in the original Digital Imaging and Communications in Medicine (DICOM) format. The CT images were anonymized and further processed using Analytic Morphomics, which has been previously described $(18,19)$. Measurements of the psoas muscle area, dorsal muscle area, and skeletal muscle area were taken from the slice at the inferior aspect of the stated vertebral body.

\section{Statistical Analyses}

The correlations between age and the MI value and the MG value of the reference cohort were quantified with the Pearson correlation coefficient $(r)$, and Hittner's method(20) was used to compare dependent correlations. Locally weighted scatterplot smoothing (LOWESS) curves were adopted. The continuous variables were summarized as the means and SDs and evaluated with Student's t-test. The categorical variables are expressed as frequencies and were analyzed with the chi-squared test. For nonnormally distributed data, the Mann-Whitney U test was used. Univariate and multivariate logistic regression was used for outcome evaluation. A significance level of p $<0.05$ was employed. All analyses were carried out using R 3.6.3(21) with packages "cocor", "finalfit", "tableone", and the data were plotted with "ggplot2".

\section{Results}

\section{Reference Cohort}

The correlations of $\mathrm{MI}$ and $\mathrm{MG}$ values with age in the reference cohort is plotted in Figure $1 \mathrm{~A}$ and 1B. The MI and MG values were significantly higher in males than in females. Previously, we found that the L4 psoas muscle index (PMI) value peaked in the $2^{\text {nd }}$ to $3^{\text {rd }}$ decade of life(15). Interestingly, other Mls, including the T12 skeletal muscle index (SMI), T12 dorsal muscle index (DMI), and L3 SMI, peaked in later stages of life. All Mls were significantly correlated with age after the age of 40, with L-spine MI values showing a steeper declining trend than T-spine indices (Supplemental Table 1). Comparing the $\mathrm{Ml}$ and $\mathrm{MG}$ values in the same muscle group, the MG values had a steadier declining trend with increasing age (Figure 1B). All MG values had significantly stronger correlations with age than did the MI values ( $r$ range from -0.55 to -0.45 , all $p<0.05$ ) after the age of 40 .

Correlations between the eight different CT-based muscle metrics were analyzed (Supplemental Table 2). The MI and MG values had moderate to strong linear relationships between the thoracic (T12) and lumbar ( $L 3, L 4)$ vertebrae, and the relationships were strongest between the L4 PMI and the L4 PMG $(r=0.89)$ and the weakest between the L4 PMG and the T12 DMI $(r=0.5)$.

\section{Definitions of Low Muscle Index(MI) and Muscle Gauge(MG) Values}

Four hundred sixty-two adults (356 males and 106 females) aged 18 to 40 were analyzed to generate Asian mean reference values for each metric. We adopted the EWGSOP consensus recommendations to define low MI or MG values as those that were two standard deviations (SD) below the sex-specific mean reference values in a healthy, young adult cohort(22). A stricter definition (very low MI or MG) was described as $2.5 \mathrm{SD}$ below the sex-specific reference values. The sex-specific cutoff values for each metric are summarized in Supplemental Table 3. The study cohort was further analyzed using these cutoff values. 
The demographics of the geriatric patients presenting with abdominal emergencies are shown in Table 1, with 660 males and 532 females included. The mean age of the cohort was $76.16 \pm 7.42$ years old. Male patients had a lower body mass index (BMI) than female patients ( $23.34 \pm 3.71$ vs. $\left.24.09 \pm 4.14 \mathrm{~kg} / \mathrm{m}^{2}, \mathrm{p}=0.001\right)$. Seventy-three patients $(6.1 \%)$ were hemodynamically unstable before surgery. The most common comorbidities were hypertension (54.4\%), followed by diabetes mellitus (24.7\%), the presence of a malignancy (14.8\%), and previous cerebrovascular accident (9.6\%). The prevalence of previous myocardial infarction, end-stage renal disease, chronic obstructive pulmonary disease, and cirrhosis were less than $5 \%$ in the cohort. Most of the patients underwent surgery due to hollow organ perforation $(22.2 \%)$, biliary disease $(20.4 \%)$, bowel obstruction $(19.9 \%)$, and appendicitis $(16.4 \%)$, with 83 patients $(7.0 \%)$ diagnosed with ischemic bowel disease. One-third of the patients $(n=381)$ underwent laparoscopic surgery. Overall complication and mortality rates in the cohort were $11.6 \%$ and $8.5 \%$, respectively. The mean length of hospital stay (LOS) was $15.27 \pm 16.56$ days, and the mean length of ICU stay (ICU LOS) was $4.04 \pm 8.41$ days. Notably, male MI and MG values were significantly higher than female MI and MG values (all $p<0.001)$.

Univariate regression analysis was performed to evaluate prognostic factors for the overall complication and mortality rates (Table 2). The variables associated with increased postoperative complications were older age (odd ratios[OR] 1.04, $\mathrm{p}<0.001$ ), unstable hemodynamics (OR 1.90, p=0.039), COPD (OR 2.96, p=0.003), ESRD (OR 2.29, $p=0.015$ ), previous cerebrovascular accident (OR 3.78, $p<0.001)$, very low $L 4$ PMI value (OR 2.52, $p<0.001)$, low $L 4$ PMG value (OR 1,77, $p=0.020)$, very low L4 PMG value $(O R 2.25, p<0.001)$, very low T12 SMG value (OR 2.59, $p<0.001)$, low L3 SMI value (OR 1.79, $p=0.013)$, very low L3 SMI value (OR 2.62, $p<0.001)$, very low L3 SMG value (OR 2.39, $\mathrm{p}<0.001)$ and very low T12 DMG value (OR 2.69, $\mathrm{p}<0.001)$.

Medical conditions associated with increased overall mortality were older age (OR 1.07, $p<0.001)$, unstable hemodynamics (OR 4.45, $p<0.001)$, cirrhosis (OR 7.91, $p<0.001)$, ESRD (OR 3.78, $p<0.001)$, previous cerebrovascular accident $(O R 3.02, p<0.001)$, and the presence of a malignancy (OR 2.31, $\mathrm{p}=0.001)$. The morphometric variables associated with increased mortality included low and very low $L 4 \mathrm{PMI}$ values (OR 1.85, $p=0.027$; OR 3.27, $p<0.001$ ), low and very low L4 PMG values (OR 2.57, $p=0.002 ; O R \quad 4.52, p<0.001$ )), very low T12 SMI value (OR 2.91, $p=0.009$ ), very low T12 SMG value (OR 3.73, $p<0.001)$, low and very low $L 3$ SMI values (OR 1.95, $p=0.011$; OR 2.61, $p=0.001$ ), low and very low L3 SMG values (OR 3.01, $p=0.013$; OR 6.35, $p<0.001)$, low and very low T12 DMI values (OR 2.29, $p=0.008 ; O R$ $2.94, p=0.001)$, and very low T12 DMG value (OR 5.72, $p<0.001)$. Diagnoses of hollow organ perforation, bowel obstruction, and ischemic bowel disease were associated with significantly higher overall complication and mortality rates than diagnoses of appendicitis and biliary disease (all $\mathrm{p}$ < 0.05). In the cohort, the laparoscopic approach was a protective factor in geriatric abdominal emergencies.

Patients were stratified by their L4 PMG values, and their characteristics are summarized in Table 3; 536 patients (45.0\%) were defined as having a normal PMG value, 287 patients $(24.1 \%)$ had a low PMG value, and 369 patients (31.0\%) had a very low L4 PMG value. The low and very low L4 PMG groups were characterized by an older age (76.63 \pm 7.16 and $78.99 \pm 7.41$ vs $73.97 \pm 6.84$ years old, $p<0.001)$ and lower BMI ( $23.06 \pm 3.84$ and $22.78 \pm 3.62$ vs $\left.24.62 \pm 3.96 \mathrm{~kg} / \mathrm{m}^{2}, p<0.001\right)$ than the normal L4 PMG group. The majority of patients with normal L4 PMG values underwent surgery due to biliary disease $(n=137,25.6 \%)$, appendicitis $(n=107,20.0 \%)$, bowel obstruction ( $n=92$, $17.2 \%)$, and hollow organ perforation $(n=90,16.8 \%)$. The most common indications for surgery in the low L4 PMG group were bowel obstruction $(n=65,22.6 \%)$, hollow organ perforation $(n=64,22.3 \%)$, biliary disease $(n=55,19.2 \%)$ and appendicitis $(n=54,18.8 \%)$. In the very low L4 PMG group, hollow organ perforation $(n=111,30.1 \%$ ) was the most common diagnosis, followed by bowel obstruction ( $n=80$, $21.7 \%)$, biliary disease $(n=51,13.8 \%)$ and appendicitis $(n=35,9.5 \%)$. A higher proportion of hemodynamically unstable patients were identified in the low and very low L4 PMG groups than in the normal group ( $6.3 \%$ and $10.3 \%$ vs $3.2 \%, p<0.001$ ).

There was no significant difference in the prevalence of comorbidities among the three groups. However, $21.7 \%$ of patients $(n=80)$ with very low L4 PMG values had a history of malignancy, which was significantly higher than the proportion in the groups with low ( $n=44$, $15.3 \%)$ and normal $(n=56,10.4 \%)$ index values. More than $40 \%$ of normal L4 PMG patients underwent laparoscopic surgery. Meanwhile, more than $70 \%$ of patients with low L4 PMG and very low L4 PMG received emergency laparotomy $(p<0.001)$.

Patients with low and very low L4 PMG values had worse surgical outcomes than those with normal L4 PMG values, with significantly longer LOS and ICU LOS and higher overall complication and mortality rates (all $\mathrm{p}<0.001$ ). Notably, the overall mortality rate of the very low L4 PMG group was nearly fourfold that of the normal group (14.9\% vs. $3.9 \%)$.

Among the CT-measured muscle metrics, L4 PMG and L3 SMG showed the highest predictive power for complications and mortality in univariate analysis. To avoid multicollinearity and because it is easy to use in the clinical environment, L4 PMG was used for multivariate analysis. 
The results of multivariate regression analysis for overall complications and mortality are shown in Table 4. Independent risk factors for increased overall complications were previous cerebrovascular accident (OR 3.03, $p<0.001)$, hollow organ perforation $(O R 2.27, p=0.043)$, bowel ischemia (OR 3.45, $p=0.007$ ), laparotomy (OR 3.13, $p=0.001$ ), and very low L4 PMG value (OR 2.11, $p=0.002)$. Meanwhile, older age (OR 1.05, $p=0.006$ ), cirrhosis (OR 12.46, $p<0.001$ ), old cerebrovascular event (OR 2.83, $p=0.001)$, bowel ischemia (OR 13.12, $p<0.001)$, laparotomy (OR 3.125, $p=0.011)$, low L4 PMG value (OR 2.24, $p=0.021)$ and very low $L 4 P M G$ value $(O R 3.41, p<0.001)$ were independent risk factors for increased overall mortality.

\section{Discussion}

The number of geriatric surgeries is increasing worldwide(23). Despite the fact that surgical outcomes have improved with the advancement of perioperative care, abdominal emergencies in elderly patients remain challenging for surgeons, and the mortality rate can exceed $20 \%(8,24)$. As the existing preoperative risk assessment tools such as the ASA classification system, CCI, and ACS NSQIP reflect underlying comorbidities, the functional and physiological status of the patients is often overlooked. Meanwhile, frailty has been reported to be an independent risk factor for adverse outcomes in elderly surgical patients $(5,25)$, and the presence of frailty is not correlated with the $\mathrm{CCl}$ score or the ASA class $(26,27)$. Currently, the traditional methods of assessing frailty are not feasible in emergency settings(4). Recent studies suggested that frailty or sarcopenia, as assessed by CT-measured skeletal muscle and psoas muscle metrics, has prognostic value for various surgical interventions and transplantation(7, 8, 28-30). As CT scans are usually performed in patients presenting with abdominal emergencies, skeletal muscle measurements can be easily obtained from the existing CT scans without any significant additional medical cost. However, there are no clear cutoff values for these CT metrics to define sarcopenia or frailty. By describing the morphometric changes in skeletal muscle with aging in the Asian population, the current study provides cutoff values to define low MG values. Low MG values in geriatric patients with abdominal emergencies were strongly associated with adverse postoperative outcomes. To our knowledge, this is the largest study to investigate the impact of low MG values in elderly patients presenting with abdominal emergencies in Asia.

As muscle mass differs with body size, the cross-sectional muscle area measured by CT imaging is often standardized with the subject's height(16). However, muscle quality is also a key component affecting functional reserve(31, 32). Fat cells replace skeletal muscle cells in the aging process, and a lower muscle intensity is detected on CT scans(11,32-34). Both skeletal $\mathrm{MI}$ and density values have been reported to be inversely associated with clinical outcomes $(8,13,35)$. Weinberg et al. first presented a SMG, which was measured by multiplying the cross-sectional skeletal muscle area by the muscle density. Shachar et al. found that the SMG was a predictor of adverse events and overall survival in a small sample of patients with metastatic breast cancer receiving chemotherapy(36). Lu et al. also found that a low total psoas gauge (TPG) value was associated with adverse outcomes in gastric cancer patients receiving radical gastrectomy(37). The current study showed that there is a correlation between MG values and aging in the Asian trauma population. Surprisingly, we found that MG values had a stronger correlation with age than did MI values, and MG values declined more rapidly after middle age. This evidence may provide a basis for further investigation of the correlations between the healthy population's functional reserve and morphometric changes in skeletal muscle during the natural aging process.

Previously, the lowest quartile in each study population was most often used to define a low skeletal muscle index or gauge value(8, 30 , $37,38)$. However, such a definition was not generalizable for all populations, as skeletal muscle mass varies widely among different study cohorts and disease entities. We hypothesized that trauma patients would constitute a random population and demonstrated the nature of the age-related decline in skeletal muscle at different vertebral levels in Asia. The mean Ml and MG values in young adults (aged 18-40) were analyzed to generate reference cutoff values for Asian populations. By adopting the EWGSOP and AWGS guidelines(9, 39), a low MI or MG value was defined as a value that was at least two SDs below the sex-specific reference values, and a stricter definition (very low) was defined as $2.5 \mathrm{SDs}$ below the reference values. We found that low T- and L-spine MG values had high predictive values for postoperative complications and mortality rates in elderly patients presenting with surgical abdomen. As all MGs were strongly correlated with each other, L4 PMG was selected for further analysis due to its ease of use in the clinical setting. Although precise measurement is essential, the L4 psoas muscle area could also be estimated without the aid of costly software(40), and muscle density could be measured in most DICOM viewers.

The ASA classification system, CCI, and ACS NSQIP have been frequently used for preoperative assessments. However, these tools have been criticized for neglecting a patient's underlying physiological reserve(41). Frailty is associated with aging, chronic comorbidities, and underweight. However, none of the available tools include frailty $(9,42-44)$. The most significant predictors of mortality in our cohort were older age, cirrhosis, past cerebrovascular events, presenting with ischemic bowel disease, and a low L4 PMG value. The strong correlations between the L4 PMG value and age and BMI are consistent with other studies $(8,29,45)$. However, we found a substantial 
predictive value of a low L4 PMG value for postoperative outcomes after adjusting for age and underlying comorbidities. Meanwhile, BMI was not a risk factor in this cohort. The result was similar to that in the study by Rangel et al.(8), who suggested that a low PMI value is a condition different from age, BMI, and comorbidities, which can provide additional information that the existing assessment tools do not.

Our overall complication (11.6\%) and mortality (8.5\%) rates were slightly lower than those reported in the literature( $(8,24,46)$. This could be attributed to the pooling of diseases with low morbidity and mortality rates, such as appendicitis and cholecystitis, which accounted for more than $30 \%$ of the cohort. A laparoscopic approach was identified as a protective factor in the cohort. However, it is important to note that the approach is determined by the surgeon depending on the patient's preoperative condition. For example, a laparotomy rather than a laparoscopic surgery was performed in an elderly patient who presented with an acute abdomen with septic shock. In the subgroup analysis, we found that $10 \%$ of patients who presented with bowel obstruction, hollow organ perforation, and bowel ischemia were in shock before the operation. Only $11 \%$ of the patients in this subgroup underwent laparoscopic surgery. These patients had higher complication (16.9\%) and mortality rates (14.3\%).

The current study had several limitations. Data were retrospectively obtained from a single tertiary care institution and there was potential for patient selection bias. As data from the "normal" population were limited $(14,47)$, MI values in the Asian trauma population were analyzed to establish reference values. Further database expansion will be necessary to support a strict morphometric definition of frailty. The retrospective and emergency nature of our study also limited the measurement of other traditional assessments of frailty, which may strengthen the predictive value of the L4 PMG. However, this study provides data that suggest that frailty, as indicated by a low L4 PMG value, is a measurement that may contribute to the improvement of the preoperative assessment of elderly surgical patients.

\section{Conclusion}

The current study was the largest study demonstrating correlations between MG values and age in the Asian population. We expect the definition of frailty as a low L4 PMG value could be useful to surgeons during preoperative counseling and surgical planning and could help optimize surgical outcomes in geriatric patients with abdominal emergencies.

\section{Abbreviations}

T12 SMI T12 Skeletal muscle index, in $\mathrm{cm}^{2} / \mathrm{m}^{2}$

T12 DMI T12 Dorsal muscle index, in $\mathrm{cm}^{2} / \mathrm{m}^{2}$

L3 SMI L3 Skeletal muscle index, in $\mathrm{cm}^{2} / \mathrm{m}^{2}$

L4 PMI L4 Psoas muscle index, in $\mathrm{cm}^{2} / \mathrm{m}^{2}$

T12 SMG T12 skeletal muscle gauge, in $\mathrm{HU}-\mathrm{cm}^{2} / \mathrm{m}^{2}$

T12 DMG T12 dorsal muscle gauge, in $\mathrm{HU}-\mathrm{cm}^{2} / \mathrm{m}^{2}$

L3 SMG L3 Skeletal muscle gauge, in $\mathrm{HU}-\mathrm{cm}^{2} / \mathrm{m}^{2}$

L4 PMG L4 Psoas muscle gauge, in $\mathrm{HU}-\mathrm{cm}^{2} / \mathrm{m}^{2}$

BMI Body mass index, in $\mathrm{kg} / \mathrm{m}^{2}$

DM Diabetes mellitus

HTN Hypertension

COPD Chronic obstructive pulmonary disease

CAD Coronary artery disease

CVA Cerebrovascular accident

ICU Intensive care unit 
LOS Length of hospital stay, in days

ICU LOS Length of intensive care unit stay, in days

CT Computed tomography

HU Hounsfield unit

SD Standard deviation

\section{Declarations}

\section{Ethics Approval and consent to participate:}

This study was approved by the ethics committee of Chang Gung Memorial Hospital (IRB No. 201601351B0C501). The requirement to obtain informed consent was waived.

\section{Consent for Publication:}

Not applicable.

Availability of supporting data:

Not applicable.

Competing interests:

Dr. Wang discloses a financial relationship with Prenovo and Morphomic Analysis Group, LLC. For the remaining co-authors, no conflicts are declared.

\section{Funding:}

This research received no funding from public, commercial or not-for-profit sectors.

\section{Authorship:}

Y.S. Tee, C.T. Cheng, S.C. Kang, C.H. Hsieh contributed to the design of the research. B.A. Derstine, G.L. Su, S.C. Wang contributed to analysis, and interpretation of the data. Y.S. Tee, C.T. Cheng, Y.T. Wu, C.P. Hsu, C.Y. Fu, C.H. Liao contributed to the acquisition and interpretation of the data. All authors critically revised, read and approved the final manuscript.

\section{Acknowledgments:}

The authors thank CDRPG3F0021, CMRPG3H0971, and CIRPG3H0021; Dr. Shih-Ching Kang, the coordinator of the CGMH trauma registry databank; and F-P Kuo, C-J Chen, and H-F Tien, members of the CGMH trauma registry databank, for their contribution to the data collection portion of the research. This study was supported by Linkou Chang Gung Memorial Hospital, grant CORP.

\section{References}

1. Sankar A, Johnson SR, Beattie WS, Tait G, Wijeysundera DN. Reliability of the American Society of Anesthesiologists physical status scale in clinical practice. Br J Anaesth. 2014;113(3):424-32.

2. Frenkel WJ, Jongerius EJ, Mandjes-van Uitert MJ, van Munster BC, de Rooij SE. Validation of the Charlson Comorbidity Index in acutely hospitalized elderly adults: a prospective cohort study. J Am Geriatr Soc. 2014;62(2):342-6.

3. Al-Temimi MH, Griffee M, Enniss TM, Preston R, Vargo D, Overton S, et al. When is death inevitable after emergency laparotomy? Analysis of the American College of Surgeons National Surgical Quality Improvement Program database. Journal of the American College of Surgeons. 2012;215(4):503-11.

4. Buta BJ, Walston JD, Godino JG, Park M, Kalyani RR, Xue QL, et al. Frailty assessment instruments: Systematic characterization of the uses and contexts of highly-cited instruments. Ageing Res Rev. 2016;26:53-61. 
5. Makary M, Segev D, Pronovost P, Syin D, Bandeen-Roche K, Patel P, et al. Frailty as a Predictor of Surgical Outcomes in Older Patients. Journal of the American College of Surgeons. 2010;210:901-8.

6. Li Y, Pederson JL, Churchill TA, Wagg AS, Holroyd-Leduc JM, Alagiakrishnan K, et al. Impact of frailty on outcomes after discharge in older surgical patients: a prospective cohort study. Cmaj. 2018;190(7):E184-e90.

7. Zuckerman J, Ades M, Mullie L, Trnkus A, Morin J-F, Langlois Y, et al. Psoas muscle area and length of stay in older adults undergoing cardiac operations. The Annals of thoracic surgery. 2017;103(5):1498-504.

8. Rangel EL, Rios-Diaz AJ, Uyeda JW, Castillo-Angeles M, Cooper Z, Olufajo OA, et al. Sarcopenia increases risk of long-term mortality in elderly patients undergoing emergency abdominal surgery. Journal of Trauma and Acute Care Surgery. 2017;83(6):1179-86.

9. Fried LP, Tangen CM, Walston J, Newman AB, Hirsch C, Gottdiener J, et al. Frailty in Older Adults: Evidence for a Phenotype. The Journals of Gerontology: Series A. 2001;56(3):M146-M57.

10. Yeh DD, Ortiz-Reyes LA, Quraishi SA, Chokengarmwong N, Avery L, Kaafarani HM, et al. Early nutritional inadequacy is associated with psoas muscle deterioration and worse clinical outcomes in critically ill surgical patients. Journal of critical care. 2018;45:7-13.

11. Boutin RD, Bamrungchart S, Bateni CP, Beavers DP, Beavers KM, Meehan JP, et al. CT of Patients With Hip Fracture: Muscle Size and Attenuation Help Predict Mortality. AJR Am J Roentgenol. 2017;208(6):W208-w15.

12. Englesbe MJ, Lee JS, He K, Fan L, Schaubel DE, Sheetz KH, et al. Analytic morphomics, core muscle size, and surgical outcomes. Annals of surgery. 2012;256(2):255-61.

13. Looijaard WGPM, Dekker IM, Stapel SN, Girbes ARJ, Twisk JWR, Oudemans-van Straaten HM, et al. Skeletal muscle quality as assessed by CT-derived skeletal muscle density is associated with 6-month mortality in mechanically ventilated critically ill patients. Critical Care. 2016;20(1):386.

14. Hamaguchi Y, Kaido T, Okumura S, Kobayashi A, Hammad A, Tamai Y, et al. Proposal for new diagnostic criteria for low skeletal muscle mass based on computed tomography imaging in Asian adults. Nutrition. 2016;32(11-12):1200-5.

15. Tee YS, Cheng CT, Wu YT, Kang SC, Derstine BA, Fu CY, et al. The psoas muscle index distribution and influence of outcomes in an Asian adult trauma population: an alternative indicator for sarcopenia of acute diseases. European journal of trauma and emergency surgery : official publication of the European Trauma Society. 2020.

16. Heymsfield SB, Heo M, Thomas D, Pietrobelli A. Scaling of body composition to height: relevance to height-normalized indexes. Am J Clin Nutr. 2011;93(4):736-40.

17. Weinberg M, Strulov Shachar S, Deal A, Williams G, Nyrop K, Alston S, et al. Characterization of skeletal muscle and body mass indices in younger and older women with stage II and III breast cancer. Journal of the American Geriatrics Society. 2016:S86.

18. Derstine B, Holcombe S, Goulson R, Ross B, Wang N, Sullivan J, et al. Quantifying sarcopenia reference values using lumbar and thoracic muscle areas in a healthy population. The journal of nutrition, health \& aging. 2018;22(1):180-5.

19. Krishnamurthy V, Zhang P, Ethiraj S, Enchakalody B, Waljee AK, Wang L, et al. Use of analytic morphomics of liver, spleen, and body composition to identify patients at risk for cirrhosis. Clinical Gastroenterology and Hepatology. 2015;13(2):360-8. e5.

20. Hittner JB, May K, Silver NC. A Monte Carlo evaluation of tests for comparing dependent correlations. The Journal of general psychology. 2003;130(2):149-68.

21. Team RC. R: A language and environment for statistical computing. 2020.

22. Cruz-Jentoft AJ, Bahat G, Bauer J, Boirie Y, Bruyere O, Cederholm T, et al. Sarcopenia: revised European consensus on definition and diagnosis. Age Ageing. 2019;48(1):16-31.

23. Gale SC, Shafi S, Dombrovskiy VY, Arumugam D, Crystal JS. The public health burden of emergency general surgery in the United States: A 10-year analysis of the Nationwide Inpatient Sample-2001 to 2010. The journal of trauma and acute care surgery. 2014;77(2):202-8.

24. Ukkonen M, Kivivuori A, Rantanen T, Paajanen H. Emergency Abdominal Operations in the Elderly: A Multivariate Regression Analysis of 430 Consecutive Patients with Acute Abdomen. World journal of surgery. 2015;39(12):2854-61.

25. Lin H-S, Watts JN, Peel NM, Hubbard RE. Frailty and post-operative outcomes in older surgical patients: a systematic review. BMC Geriatrics. 2016;16(1):157.

26. Englesbe MJ, Patel SP, He K, Lynch RJ, Schaubel DE, Harbaugh C, et al. Sarcopenia and mortality after liver transplantation. Journal of the American College of Surgeons. 2010;211(2):271-8.

27. Du Y, Karvellas CJ, Baracos V, Williams DC, Khadaroo RG. Sarcopenia is a predictor of outcomes in very elderly patients undergoing emergency surgery. Surgery. 2014;156(3):521-7. 
28. Chae MS, Moon KU, Jung JY, Choi HJ, Chung HS, Park CS, et al. Perioperative loss of psoas muscle is associated with patient survival in living donor liver transplantation. Liver transplantation : official publication of the American Association for the Study of Liver Diseases and the International Liver Transplantation Society. 2018;24(5):623-33.

29. Hsu J, Krishnan A, Lin CT, Shah PD, Broderick SR, Higgins RSD, et al. Sarcopenia of the Psoas Muscles Is Associated With Poor Outcomes Following Lung Transplantation. Ann Thorac Surg. 2019;107(4):1082-8.

30. Francomacaro LM, Walker C, Jaap K, Dove J, Hunsinger M, Widom K, et al. Sarcopenia predicts poor outcomes in urgent exploratory laparotomy. The American Journal of Surgery. 2018;216(6):1107-13.

31. Williams GR, Deal AM, Muss HB, Weinberg MS, Sanoff HK, Nyrop KA, et al. Skeletal muscle measures and physical function in older adults with cancer: sarcopenia or myopenia? Oncotarget. 2017;8(20):33658-65.

32. Aubrey J, Esfandiari N, Baracos VE, Buteau FA, Frenette J, Putman CT, et al. Measurement of skeletal muscle radiation attenuation and basis of its biological variation. Acta Physiol (Oxf). 2014;210(3):489-97.

33. Zamboni M, Mazzali G, Fantin F, Rossi A, Di Francesco V. Sarcopenic obesity: a new category of obesity in the elderly. Nutr Metab Cardiovasc Dis. 2008;18(5):388-95.

34. Goodpaster BH, Kelley DE, Thaete FL, He J, Ross R. Skeletal muscle attenuation determined by computed tomography is associated with skeletal muscle lipid content. J Appl Physiol (1985). 2000;89(1):104-10.

35. van Baar H, Beijer S, Bours MJL, Weijenberg MP, van Zutphen M, van Duijnhoven FJB, et al. Low radiographic muscle density is associated with lower overall and disease-free survival in early-stage colorectal cancer patients. J Cancer Res Clin Oncol. 2018;144(11):2139-47.

36. Shachar SS, Deal AM, Weinberg M, Nyrop KA, Williams GR, Nishijima TF, et al. Skeletal Muscle Measures as Predictors of Toxicity, Hospitalization, and Survival in Patients with Metastatic Breast Cancer Receiving Taxane-Based Chemotherapy. Clin Cancer Res. 2017;23(3):658-65.

37. Lu J, Zheng Z-F, Li P, Xie J-W, Wang J-B, Lin J-X, et al. A Novel Preoperative Skeletal Muscle Measure as a Predictor of Postoperative Complications, Long-Term Survival and Tumor Recurrence for Patients with Gastric Cancer After Radical Gastrectomy. Annals of surgical oncology. 2018;25(2):439-48.

38. Kalafateli M, Mantzoukis K, Choi Yau Y, Mohammad AO, Arora S, Rodrigues S, et al. Malnutrition and sarcopenia predict post-liver transplantation outcomes independently of the Model for End-stage Liver Disease score. J Cachexia Sarcopenia Muscle. 2017;8(1):113-21.

39. Chen LK, Liu LK, Woo J, Assantachai P, Auyeung TW, Bahyah KS, et al. Sarcopenia in Asia: consensus report of the Asian Working Group for Sarcopenia. J Am Med Dir Assoc. 2014;15(2):95-101.

40. Jones KI, Doleman B, Scott S, Lund JN, Williams JP. Simple psoas cross-sectional area measurement is a quick and easy method to assess sarcopenia and predicts major surgical complications. Colorectal disease : the official journal of the Association of Coloproctology of Great Britain and Ireland. 2015;17(1):020-6.

41. Visnjevac O, Davari-Farid S, Lee J, Pourafkari L, Arora P, Dosluoglu HH, et al. The Effect of Adding Functional Classification to ASA Status for Predicting 30-Day Mortality. Anesthesia \& Analgesia. 2015;121(1):110-6.

42. Hamerman D. Toward an understanding of frailty. Ann Intern Med. 1999;130(11):945-50.

43. Newman AB, Gottdiener JS, McBurnie MA, Hirsch CH, Kop WJ, Tracy R, et al. Associations of subclinical cardiovascular disease with frailty. J Gerontol A Biol Sci Med Sci. 2001;56(3):M158-66.

44. Walston J. Frailty-the search for underlying causes. Sci Aging Knowledge Environ. 2004;2004(4):pe4.

45. Okamura H, Kimura N, Tanno K, Mieno M, Matsumoto H, Yamaguchi A, et al. The impact of preoperative sarcopenia, defined based on psoas muscle area, on long-term outcomes of heart valve surgery. The Journal of thoracic and cardiovascular surgery. 2019;157(3):1071-9. e3.

46. Fukuda N, Wada J, Niki M, Sugiyama Y, Mushiake H. Factors predicting mortality in emergency abdominal surgery in the elderly. World Journal of Emergency Surgery. 2012;7(1):12.

47. Derstine BA, Holcombe SA, Ross BE, Wang NC, Su GL, Wang SC. Skeletal muscle cutoff values for sarcopenia diagnosis using T10 to L5 measurements in a healthy US population. Scientific reports. 2018;8(1):11369.

\section{Tables}

Table 1. Characteristics of elderly patients presenting with abdominal emergencies 


\begin{tabular}{|c|c|c|c|}
\hline & Male & Female & p-value \\
\hline Number & 660 & 532 & \\
\hline Age, mean (SD) & $75.84(7.16)$ & $76.57(7.71)$ & 0.092 \\
\hline BMI, mean (SD) & $23.34(3.71)$ & $24.09(4.14)$ & $0.001^{*}$ \\
\hline Hemodynamic unstable (\%) & $40(6.1)$ & $33(6.2)$ & 1.000 \\
\hline Laparoscopic surgery, n (\%) & $194(29.4)$ & $187(35.2)$ & 0.039 \\
\hline Diagnosis, $\mathrm{n}(\%)$. & & & 0.393 \\
\hline Appendicitis & $99(15.0)$ & $97(18.2)$ & \\
\hline Biliary disease & $140(21.2)$ & $103(19.4)$ & \\
\hline Hollow organ perforation & $144(21.8)$ & $121(22.7)$ & \\
\hline Intestinal obstruction & $134(20.3)$ & $103(19.4)$ & \\
\hline Mesenteric ischemia & $53(8.0)$ & $30(5.6)$ & \\
\hline Others & $90(13.6)$ & $78(14.7)$ & \\
\hline \multicolumn{4}{|l|}{ Comorbidities } \\
\hline Diabetes mellitus, $\mathrm{n}(\%)$ & $154(23.3)$ & $140(26.3)$ & 0.251 \\
\hline Hypertension, n (\%) & $337(51.1)$ & $311(58.5)$ & $0.012^{*}$ \\
\hline COPD, n (\%) & $39(5.9)$ & $2(0.4)$ & $<0.001^{*}$ \\
\hline Cirrhosis, n (\%) & $19(2.9)$ & $14(2.6)$ & 0.860 \\
\hline ESRD, n (\%) & $30(4.5)$ & $24(4.5)$ & 1.000 \\
\hline Coronary artery disease, n (\%) & $37(5.6)$ & $18(3.4)$ & 0.072 \\
\hline Cerebral vascular disease, n (\%) & $68(10.3)$ & $46(8.6)$ & 0.373 \\
\hline Cancer, n (\%) & $108(16.4)$ & $68(12.8)$ & 0.085 \\
\hline \multicolumn{4}{|l|}{ Muscle Metrics } \\
\hline PMI L4, mean (SD) & $7.06(1.77)$ & $5.08(1.37)$ & $<0.001^{*}$ \\
\hline SMI T12, mean (SD) & $32.68(6.33)$ & $28.15(5.32)$ & $<0.001^{*}$ \\
\hline SMI L3, mean (SD) & $43.22(7.61)$ & $36.51(6.08)$ & $<0.001^{*}$ \\
\hline DMI T12, mean (SD) & $11.20(3.14)$ & $10.36(2.81)$ & $<0.001 *$ \\
\hline PMG L4, mean (SD) & $323.46(116.50)$ & $231.17(90.85)$ & $<0.001^{*}$ \\
\hline SMG T12, mean (SD) & $1123.40(346.86)$ & $872.42(293.19)$ & $<0.001 *$ \\
\hline SMG L3, mean (SD) & $1480.51(502.08)$ & $1103.69(412.39)$ & $<0.001^{*}$ \\
\hline DMG T12, mean (SD) & $419.99(178.26)$ & $357.48(160.33)$ & $<0.001 *$ \\
\hline
\end{tabular}

Abbreviations: SD, standard deviation; BMI, body mass index; COPD, chronic obstructive pulmonary disease; ESRD, end stage renal disease; CAD, coronary artery disease; CVA, cerebrovascular accident; PMI, psoas muscle index; SMI, skeletal muscle index; DMI, dorsal muscle group index; PMG, psoas muscle gauge; SMG, skeletal muscle gauge, DMG, dorsal muscle group gauge

*statistically significant

Table 2. Univariate analysis of risk factors for complications and mortality among elderly patients presenting with abdominal emergencies 


\begin{tabular}{|c|c|c|c|c|c|c|c|c|c|}
\hline & & $\begin{array}{l}\text { No } \\
\text { complications }\end{array}$ & $\begin{array}{l}\text { With } \\
\text { complications }\end{array}$ & $\begin{array}{l}\text { OR } \\
(95 \% \\
\text { Cl) }\end{array}$ & $\mathrm{p}$ value & Survivors & Nonsurvivors & $\begin{array}{l}\text { OR } \\
(95 \% \\
\text { Cl) }\end{array}$ & $\mathrm{p}$ value \\
\hline $\begin{array}{l}\text { Age, years, } \\
\text { mean (SD) }\end{array}$ & & 75.9 (7.3) & $78.3(8.0)$ & $\begin{array}{l}1.04 \\
(1.02- \\
1.07)\end{array}$ & $<0.001^{*}$ & $\begin{array}{l}75.8 \\
(7.3)\end{array}$ & $79.6(7.5)$ & $\begin{array}{l}1.07 \\
(1.04- \\
1.10)\end{array}$ & $<0.001^{*}$ \\
\hline \multirow[t]{2}{*}{ Sex } & $\begin{array}{l}\text { female, } \\
\text { n (\%) }\end{array}$ & $476(89.5)$ & $56(10.5)$ & & & $\begin{array}{l}486 \\
(91.4)\end{array}$ & $46(8.6)$ & & \\
\hline & $\operatorname{male}_{(\%)} n$ & 578 (87.6) & $82(12.4)$ & $\begin{array}{l}1.21 \\
(0.84- \\
1.74)\end{array}$ & 0.309 & $\begin{array}{l}605 \\
(91.7)\end{array}$ & $55(8.3)$ & $\begin{array}{l}0.96 \\
(0.64- \\
1.45)\end{array}$ & 0.847 \\
\hline $\begin{array}{l}\mathrm{BMI}, \mathrm{kg} / \mathrm{m}^{2} \\
\text { mean (SD) }\end{array}$ & & 23.7 (3.9) & $23.5(4.2)$ & $\begin{array}{l}0.99 \\
(0.94- \\
1.03)\end{array}$ & 0.563 & $\begin{array}{l}23.7 \\
(3.9)\end{array}$ & $23.3(3.9)$ & $\begin{array}{l}0.97 \\
(0.92- \\
1.02)\end{array}$ & 0.268 \\
\hline \multirow[t]{2}{*}{ Hemodynamics } & $\begin{array}{l}\text { stable, } \mathrm{n} \\
(\%)\end{array}$ & 995 (88.9) & $124(11.1)$ & & & $\begin{array}{l}1037 \\
(92.7)\end{array}$ & $82(7.3)$ & & \\
\hline & $\begin{array}{l}\text { unstable, } \\
\mathrm{n}(\%)\end{array}$ & $59(80.8)$ & $14(19.2)$ & $\begin{array}{l}1.90 \\
(1.00- \\
3.42)\end{array}$ & $0.039 *$ & $54(74.0)$ & $19(26.0)$ & $\begin{array}{l}4.45 \\
(2.47- \\
7.75)\end{array}$ & $<0.001 *$ \\
\hline \multicolumn{10}{|l|}{ Comorbidities } \\
\hline \multirow[t]{2}{*}{$\begin{array}{l}\text { Diabetes } \\
\text { mellitus }\end{array}$} & no, n (\%) & 795 (88.5) & 103 (11.5) & & & $\begin{array}{l}826 \\
(92.0)\end{array}$ & $72(8.0)$ & & \\
\hline & $\begin{array}{l}\text { yes, n } \\
(\%)\end{array}$ & $259(88.1)$ & 35 (11.9) & $\begin{array}{l}1.04 \\
(0.69- \\
1.55)\end{array}$ & 0.840 & $\begin{array}{l}265 \\
(90.1)\end{array}$ & $29(9.9)$ & $\begin{array}{l}1.26 \\
(0.79- \\
1.95)\end{array}$ & 0.325 \\
\hline \multirow[t]{2}{*}{ Hypertension } & no, n (\%) & $490(90.1)$ & $54(9.9)$ & & & $\begin{array}{l}504 \\
(92.6)\end{array}$ & $40(7.4)$ & & \\
\hline & $\begin{array}{l}\text { yes, } n \\
(\%)\end{array}$ & $564(87.0)$ & $84(13.0)$ & $\begin{array}{l}1.35 \\
(0.94- \\
1.95)\end{array}$ & 0.104 & $\begin{array}{l}587 \\
(90.6)\end{array}$ & $61(9.4)$ & $\begin{array}{l}1.31 \\
(0.87- \\
2.00)\end{array}$ & 0.204 \\
\hline \multirow[t]{2}{*}{ COPD } & no, n (\%) & $1024(89.0)$ & $127(11.0)$ & & & $\begin{array}{l}1054 \\
(91.6)\end{array}$ & 97 (8.4) & & \\
\hline & $\begin{array}{l}\text { yes, n } \\
(\%)\end{array}$ & $30(73.2)$ & $11(26.8)$ & $\begin{array}{l}2.96 \\
(1.39- \\
5.88)\end{array}$ & $0.003^{*}$ & 37 (90.2) & $4(9.8)$ & $\begin{array}{l}1.17 \\
(0.35- \\
3.01)\end{array}$ & 0.764 \\
\hline \multirow[t]{2}{*}{ Cirrhosis } & no, n (\%) & 1027 (88.6) & $132(11.4)$ & & & $\begin{array}{l}1071 \\
(92.4)\end{array}$ & $88(7.6)$ & & \\
\hline & $\begin{array}{l}\text { yes, } n \\
(\%)\end{array}$ & $27(81.8)$ & $6(18.2)$ & $\begin{array}{l}1.73 \\
(0.64- \\
4.00)\end{array}$ & 0.235 & $20(60.6)$ & $13(39.4)$ & $\begin{array}{l}7.91 \\
(3.72- \\
16.2)\end{array}$ & $<0.001^{*}$ \\
\hline \multirow[t]{2}{*}{ ESRD } & no, n (\%) & 1012 (88.9) & $126(11.1)$ & & & $\begin{array}{l}1050 \\
(92.3)\end{array}$ & $88(7.7)$ & & \\
\hline & $\begin{array}{l}\text { yes, } n \\
(\%)\end{array}$ & $42(77.8)$ & $12(22.2)$ & $\begin{array}{l}2.29 \\
(1.13- \\
4.34)\end{array}$ & $0.015^{\star}$ & 41 (75.9) & $13(24.1)$ & $\begin{array}{l}3.78 \\
(1.89- \\
7.15)\end{array}$ & $<0.001 *$ \\
\hline
\end{tabular}




\begin{tabular}{|c|c|c|c|c|c|c|c|c|c|}
\hline & & $\begin{array}{l}\text { No } \\
\text { complications }\end{array}$ & $\begin{array}{l}\text { With } \\
\text { complications }\end{array}$ & $\begin{array}{l}\text { OR } \\
(95 \% \mathrm{Cl})\end{array}$ & $\mathrm{p}$ value & Survivors & Nonsurvivors & $\begin{array}{l}\text { OR } \\
(95 \% \mathrm{Cl})\end{array}$ & $\mathrm{p}$ value \\
\hline \multirow[t]{2}{*}{ CAD } & $\begin{array}{l}\text { no, n } \\
(\%)\end{array}$ & $1010(88.8)$ & $127(11.2)$ & & & $\begin{array}{l}1042 \\
(91.6)\end{array}$ & $95(8.4)$ & & \\
\hline & $\begin{array}{l}\text { yes, } \\
\text { n (\%) }\end{array}$ & $44(80.0)$ & $11(20.0)$ & $\begin{array}{l}1.99 \\
(0.96- \\
3.82)\end{array}$ & 0.050 & $49(89.1)$ & $6(10.9)$ & $\begin{array}{l}1.34 \\
(0.50- \\
2.99)\end{array}$ & 0.508 \\
\hline \multirow[t]{2}{*}{ CVA } & $\begin{array}{l}\text { no, n } \\
(\%)\end{array}$ & $973(90.3)$ & 105 (9.7) & & & $\begin{array}{l}999 \\
(92.7)\end{array}$ & $79(7.3)$ & & \\
\hline & $\begin{array}{l}\text { yes, } \\
\text { n (\%) }\end{array}$ & $81(71.1)$ & $33(28.9)$ & $\begin{array}{l}3.78 \\
(2.38- \\
5.89)\end{array}$ & $<0.001^{\star}$ & $92(80.7)$ & $22(19.3)$ & $\begin{array}{l}3.02 \\
(1.77- \\
5.01)\end{array}$ & $<0.001^{*}$ \\
\hline \multirow[t]{2}{*}{ Cancer } & $\begin{array}{l}\text { no, n } \\
(\%)\end{array}$ & $906(89.2)$ & $110(10.8)$ & & & $\begin{array}{l}942 \\
(92.7)\end{array}$ & $74(7.3)$ & & \\
\hline & $\begin{array}{l}\text { yes, } \\
\text { n (\%) }\end{array}$ & $148(84.1)$ & $28(15.9)$ & $\begin{array}{l}1.56 \\
(0.98- \\
2.41)\end{array}$ & 0.053 & $\begin{array}{l}149 \\
(84.7)\end{array}$ & $27(15.3)$ & $\begin{array}{l}2.31 \\
(1.42- \\
3.66)\end{array}$ & $0.001 *$ \\
\hline \multicolumn{10}{|c|}{ Diagnosis } \\
\hline \multicolumn{2}{|c|}{ Appendicitis, n (\%) } & $187(95.4)$ & $9(4.6)$ & & & $\begin{array}{l}192 \\
(98.0)\end{array}$ & $4(2.0)$ & & \\
\hline \multicolumn{2}{|c|}{$\begin{array}{l}\text { Biliary disease, } n \\
(\%)\end{array}$} & $228(93.8)$ & $15(6.2)$ & $\begin{array}{l}1.37 \\
(0.59- \\
3.32)\end{array}$ & 0.470 & $\begin{array}{l}236 \\
(97.1)\end{array}$ & $7(2.9)$ & $\begin{array}{l}1.42 \\
(0.42- \\
5.50)\end{array}$ & 0.578 \\
\hline \multicolumn{2}{|c|}{$\begin{array}{l}\text { Hollow organ } \\
\text { perforation, } \mathrm{n}(\%)\end{array}$} & 218 (82.3) & 47 (17.7) & $\begin{array}{l}4.48 \\
(2.24- \\
9.99)\end{array}$ & $<0.001 *$ & $\begin{array}{l}230 \\
(86.8)\end{array}$ & $35(13.2)$ & $\begin{array}{l}7.30 \\
(2.86- \\
24.7)\end{array}$ & $<0.001^{*}$ \\
\hline \multicolumn{2}{|c|}{$\begin{array}{l}\text { Intestinal } \\
\text { obstruction, n (\%) }\end{array}$} & $207(87.3)$ & $30(12.7)$ & $\begin{array}{l}3.01 \\
(1.45- \\
6.89)\end{array}$ & $0.005^{\star}$ & $\begin{array}{l}218 \\
(92.0)\end{array}$ & $19(8.0)$ & $\begin{array}{l}4.18 \\
(1.54- \\
14.6)\end{array}$ & $0.010^{*}$ \\
\hline \multicolumn{2}{|c|}{$\begin{array}{l}\text { Mesenteric } \\
\text { ischemia, } \mathrm{n}(\%)\end{array}$} & $61(73.5)$ & $22(26.5)$ & $\begin{array}{l}7.49 \\
(3.37- \\
17.9)\end{array}$ & $<0.001^{\star}$ & $53(63.9)$ & $30(36.1)$ & $\begin{array}{l}27.17 \\
(10.18- \\
94)\end{array}$ & $<0.001^{*}$ \\
\hline \multicolumn{2}{|c|}{ Others, $\mathrm{n}(\%)$} & $153(91.1)$ & $15(8.9)$ & $\begin{array}{l}2.04 \\
(0.88- \\
4.97)\end{array}$ & 0.102 & $\begin{array}{l}162 \\
(96.4)\end{array}$ & $6(3.6)$ & $\begin{array}{l}1.78 \\
(0.50- \\
7.05)\end{array}$ & 0.379 \\
\hline \multicolumn{10}{|c|}{$\begin{array}{l}\text { Surgical } \\
\text { procedure }\end{array}$} \\
\hline \multicolumn{2}{|c|}{$\begin{array}{l}\text { Laparoscopy, n } \\
(\%)\end{array}$} & $368(96.6)$ & $13(3.4)$ & & & $\begin{array}{l}374 \\
(98.2)\end{array}$ & $7(1.8)$ & & \\
\hline \multicolumn{2}{|c|}{ Laparotomy, n (\%) } & $686(84.6)$ & $125(15.4)$ & $\begin{array}{l}5.26(2.94- \\
10.00)\end{array}$ & $<0.001 *$ & $\begin{array}{l}717 \\
(88.4)\end{array}$ & $94(11.6)$ & $\begin{array}{l}7.14(3.45- \\
16.67)\end{array}$ & $<0.001^{*}$ \\
\hline
\end{tabular}




\begin{tabular}{|c|c|c|c|c|c|c|c|c|c|}
\hline & & $\begin{array}{l}\text { No } \\
\text { complications }\end{array}$ & $\begin{array}{l}\text { With } \\
\text { complications }\end{array}$ & $\begin{array}{l}\text { OR } \\
(95 \% \mathrm{Cl})\end{array}$ & $p$ value & Survivors & Nonsurvivors & $\begin{array}{l}\text { OR } \\
(95 \% \\
\mathrm{Cl})\end{array}$ & $p$ value \\
\hline \multicolumn{10}{|c|}{$\begin{array}{l}\text { Muscle } \\
\text { metrics }\end{array}$} \\
\hline \multirow[t]{3}{*}{$\begin{array}{l}\text { PMI } \\
\text { L4 }\end{array}$} & $\begin{array}{l}\text { normal, } \mathrm{n} \\
(\%)\end{array}$ & $586(91.7)$ & $53(8.3)$ & & & & & & \\
\hline & low, n (\%) & 231 (88.2) & $31(11.8)$ & $\begin{array}{l}1.48(0.92- \\
2.36)\end{array}$ & 0.099 & $\begin{array}{l}606 \\
(94.8)\end{array}$ & $33(5.2)$ & $\begin{array}{l}1.85 \\
(1.06- \\
3.19)\end{array}$ & $0.027^{*}$ \\
\hline & $\begin{array}{l}\text { very low, } \\
\mathrm{n}(\%)\end{array}$ & 237 (81.4) & 54 (18.6) & $\begin{array}{l}2.52(1.67- \\
3.79)\end{array}$ & $<0.001^{\star}$ & $\begin{array}{l}238 \\
(90.8)\end{array}$ & $24(9.2)$ & $\begin{array}{l}3.27 \\
(2.04- \\
5.29)\end{array}$ & $<0.001^{\star}$ \\
\hline \multirow[t]{3}{*}{$\begin{array}{l}\text { PMG } \\
\text { L4 }\end{array}$} & $\begin{array}{l}\text { normal, } \mathrm{n} \\
(\%)\end{array}$ & 497 (92.7) & $39(7.3)$ & & & $\begin{array}{l}247 \\
(84.9)\end{array}$ & $44(15.1)$ & & \\
\hline & low, n (\%) & 252 (87.8) & 35 (12.2) & $\begin{array}{l}1.77(1.09- \\
2.86)\end{array}$ & $0.020^{\star}$ & $\begin{array}{l}516 \\
(96.3)\end{array}$ & $20(3.7)$ & $\begin{array}{l}2.57 \\
(1.41- \\
4.74)\end{array}$ & $0.002^{\star}$ \\
\hline & $\begin{array}{l}\text { very low, } \\
\mathrm{n}(\%)\end{array}$ & 305 (82.7) & $64(17.3)$ & $\begin{array}{l}2.67(1.76- \\
4.11)\end{array}$ & $<0.001^{\star}$ & $\begin{array}{l}261 \\
(90.9)\end{array}$ & $26(9.1)$ & $\begin{array}{l}4.52 \\
(2.70- \\
7.85)\end{array}$ & $<0.001^{*}$ \\
\hline \multirow[t]{3}{*}{$\begin{array}{l}\text { SMI } \\
\text { T12 }\end{array}$} & $\begin{array}{l}\text { normal, } \mathrm{n} \\
(\%)\end{array}$ & 934 (88.8) & 118 (11.2) & & & $\begin{array}{l}314 \\
(85.1)\end{array}$ & $55(14.9)$ & & \\
\hline & low, n (\%) & $84(84.8)$ & $15(15.2)$ & $\begin{array}{l}1.41(0.76- \\
2.46)\end{array}$ & 0.244 & $\begin{array}{l}971 \\
(92.3)\end{array}$ & $81(7.7)$ & $\begin{array}{l}1.65 \\
(0.83- \\
3.04)\end{array}$ & 0.126 \\
\hline & $\begin{array}{l}\text { very low, } \\
\mathrm{n}(\%)\end{array}$ & $36(87.8)$ & $5(12.2)$ & $\begin{array}{l}1.10(0.37- \\
2.62)\end{array}$ & 0.846 & 87 (87.9) & $12(12.1)$ & $\begin{array}{l}2.91 \\
(1.22- \\
6.21)\end{array}$ & $0.009 *$ \\
\hline \multirow[t]{3}{*}{$\begin{array}{l}\text { SMG } \\
\text { T12 }\end{array}$} & $\begin{array}{l}\text { normal, } \mathrm{n} \\
(\%)\end{array}$ & 359 (93.5) & $25(6.5)$ & & & $33(80.5)$ & $8(19.5)$ & & \\
\hline & low, n (\%) & $213(89.1)$ & $26(10.9)$ & $\begin{array}{l}1.75(0.98- \\
3.13)\end{array}$ & 0.056 & $\begin{array}{l}369 \\
(96.1)\end{array}$ & $15(3.9)$ & $\begin{array}{l}1.19 \\
(0.52- \\
2.61)\end{array}$ & 0.673 \\
\hline & $\begin{array}{l}\text { very low, } \\
\mathrm{n}(\%)\end{array}$ & 482 (84.7) & 87 (15.3) & $\begin{array}{l}2.59(1.65- \\
4.21)\end{array}$ & $<0.001^{\star}$ & $\begin{array}{l}228 \\
(95.4)\end{array}$ & $11(4.6)$ & $\begin{array}{l}3.73 \\
(2.17- \\
6.85)\end{array}$ & $<0.001^{\star}$ \\
\hline \multirow[t]{3}{*}{$\begin{array}{l}\text { SMI } \\
\text { L3 }\end{array}$} & $\begin{array}{l}\text { normal, } \mathrm{n} \\
(\%)\end{array}$ & $823(90.4)$ & $87(9.6)$ & & & $\begin{array}{l}494 \\
(86.8)\end{array}$ & $75(13.2)$ & & \\
\hline & low, n (\%) & $148(84.1)$ & $28(15.9)$ & $\begin{array}{l}1.79(1.11- \\
2.80)\end{array}$ & $0.013^{*}$ & $\begin{array}{l}848 \\
(93.2)\end{array}$ & $62(6.8)$ & $\begin{array}{l}1.95 \\
(1.14- \\
3.23)\end{array}$ & $0.011^{*}$ \\
\hline & $\begin{array}{l}\text { very low, } \\
\mathrm{n}(\%)\end{array}$ & 83 (78.3) & $23(21.7)$ & $\begin{array}{l}2.62(1.54- \\
4.32)\end{array}$ & $<0.001^{\star}$ & $\begin{array}{l}154 \\
(87.5)\end{array}$ & $22(12.5)$ & $\begin{array}{l}2.61 \\
(1.43- \\
4.57)\end{array}$ & $0.001^{*}$ \\
\hline \multirow[t]{3}{*}{$\begin{array}{l}\text { SMG } \\
\text { L3 }\end{array}$} & $\begin{array}{l}\text { normal, } \mathrm{n} \\
(\%)\end{array}$ & 327 (93.2) & $24(6.8)$ & & & $89(84.0)$ & $17(16.0)$ & & \\
\hline & low, n (\%) & 219 (89.8) & $25(10.2)$ & $\begin{array}{l}1.56(0.86- \\
2.81)\end{array}$ & 0.139 & $\begin{array}{l}343 \\
(97.7)\end{array}$ & $8(2.3)$ & $\begin{array}{l}3.01 \\
(1.30- \\
7.53)\end{array}$ & $0.013^{*}$ \\
\hline & $\begin{array}{l}\text { very low, } \\
\mathrm{n}(\%)\end{array}$ & 508 (85.1) & 89 (14.9) & $\begin{array}{l}2.39(1.51- \\
3.90)\end{array}$ & $<0.001^{\star}$ & $\begin{array}{l}228 \\
(93.4)\end{array}$ & $16(6.6)$ & $\begin{array}{l}6.35 \\
(3.22- \\
14.4)\end{array}$ & $<0.001^{*}$ \\
\hline $\begin{array}{l}\text { DMI } \\
\text { T12 }\end{array}$ & $\begin{array}{l}\text { normal, } \mathrm{n} \\
(\%)\end{array}$ & $905(89.1)$ & $111(10.9)$ & & & $\begin{array}{l}520 \\
(87.1)\end{array}$ & 77 (12.9) & & \\
\hline
\end{tabular}

Page 13/17 


\begin{tabular}{|c|c|c|c|c|c|c|c|c|c|}
\hline & low, n (\%) & $80(85.1)$ & 14 (14.9) & $\begin{array}{l}1.43(0.75- \\
2.53)\end{array}$ & 0.246 & $\begin{array}{l}944 \\
(92.9)\end{array}$ & $72(7.1)$ & $\begin{array}{l}2.29 \\
(1.20- \\
4.14)\end{array}$ & $0.008^{*}$ \\
\hline & $\begin{array}{l}\text { very low, } \\
\mathrm{n}(\%)\end{array}$ & 69 (84.1) & 13 (15.9) & $\begin{array}{l}1.54(0.79- \\
2.78)\end{array}$ & 0.178 & $80(85.1)$ & 14 (14.9) & $\begin{array}{l}2.94 \\
(1.55- \\
5.27)\end{array}$ & $0.001^{\star}$ \\
\hline \multirow[t]{3}{*}{$\begin{array}{l}\text { DMG } \\
\text { T12 }\end{array}$} & $\begin{array}{l}\text { normal, } \mathrm{n} \\
(\%)\end{array}$ & 455 (92.9) & $35(7.1)$ & & & 67 (81.7) & 15 (18.3) & & \\
\hline & low, n (\%) & 198 (90.8) & $20(9.2)$ & $\begin{array}{l}1.31(0.73- \\
2.31)\end{array}$ & 0.352 & $\begin{array}{l}475 \\
(96.9)\end{array}$ & $15(3.1)$ & $\begin{array}{l}1.84 \\
(0.83- \\
4.00)\end{array}$ & 0.122 \\
\hline & $\begin{array}{l}\text { very low, } \\
\mathrm{n}(\%)\end{array}$ & 401 (82.9) & $83(17.1)$ & $\begin{array}{l}2.69 \text { (1.79- } \\
4.13)\end{array}$ & $<0.001 *$ & $\begin{array}{l}206 \\
(94.5)\end{array}$ & $12(5.5)$ & $\begin{array}{l}5.72 \\
(3.32- \\
10.4)\end{array}$ & $<0.001$ * \\
\hline
\end{tabular}

Abbreviations: SD, standard deviation; BMI, body mass index; COPD, chronic obstructive pulmonary disease; ESRD, end-stage renal disease; CAD, coronary artery disease; CVA, cerebrovascular accident; PMI, psoas muscle index; SMI, skeletal muscle index; DMI, dorsal muscle group index; PMG, psoas muscle gauge; SMG, skeletal muscle gauge, DMG, dorsal muscle group gauge

*statistically significant

Table 3. Characteristics of elderly patients presenting with abdominal emergencies stratified by L4 PMG values 


\begin{tabular}{|c|c|c|c|c|}
\hline & \multicolumn{3}{|c|}{ L4 PMG } & \multirow[b]{2}{*}{ p-value } \\
\hline & Normal & Low & Very low & \\
\hline Number & 536 & 287 & 369 & \\
\hline Age, years, mean (SD) & $73.97(6.84)$ & $76.63(7.16)$ & $78.99(7.41)$ & $<0.001^{*}$ \\
\hline Sex, male (\%) & $297(55.4)$ & $169(58.9)$ & $194(52.6)$ & 0.276 \\
\hline BMI, mean (SD) & $24.62(3.96)$ & $23.06(3.84)$ & $22.78(3.62)$ & $<0.001^{*}$ \\
\hline Hemodynamic unstable (\%) & $17(3.2)$ & $18(6.3)$ & $38(10.3)$ & $<0.001^{*}$ \\
\hline Laparoscopic surgery, n (\%) & $221(41.2)$ & $80(27.9)$ & $80(21.7)$ & $<0.001^{*}$ \\
\hline Primary diagnosis, $\mathrm{n}(\%)$ & & & & $<0.001 *$ \\
\hline Appendicitis & $107(20.0)$ & $54(18.8)$ & $35(9.5)$ & \\
\hline Biliary disease & $137(25.6)$ & $55(19.2)$ & $51(13.8)$ & \\
\hline Hollow organ perforation & $90(16.8)$ & $64(22.3)$ & $111(30.1)$ & \\
\hline Intestinal obstruction & $92(17.2)$ & $65(22.6)$ & $80(21.7)$ & \\
\hline Mesenteric ischemia & $33(6.2)$ & $22(7.7)$ & $28(7.6)$ & \\
\hline Others & $77(14.4)$ & $27(9.4)$ & $64(17.3)$ & \\
\hline \multicolumn{5}{|l|}{ Comorbidities } \\
\hline Diabetes mellitus, n (\%) & $126(23.5)$ & $79(27.5)$ & $89(24.1)$ & 0.426 \\
\hline Hypertension, n (\%) & $288(53.7)$ & $153(53.3)$ & $207(56.1)$ & 0.726 \\
\hline COPD, n (\%) & $14(2.6)$ & $13(4.5)$ & $14(3.8)$ & 0.294 \\
\hline Cirrhosis, n (\%) & $15(2.8)$ & $7(2.4)$ & $11(3.0)$ & 0.949 \\
\hline ESRD, n (\%) & $16(3.0)$ & $16(5.6)$ & $22(6.0)$ & 0.061 \\
\hline Coronary artery disease, $\mathrm{n}(\%)$ & $25(4.7)$ & $15(5.2)$ & $15(4.1)$ & 0.769 \\
\hline Cerebral vascular disease, $\mathrm{n}(\%)$ & $50(9.3)$ & $23(8.0)$ & $41(11.1)$ & 0.41 \\
\hline Cancer, $\mathrm{n}(\%)$ & $56(10.4)$ & $44(15.3)$ & $76(20.6)$ & $<0.001^{*}$ \\
\hline \multicolumn{5}{|l|}{ Outcome } \\
\hline Length of hospital stay, days (mean (SD)) & 12.85 (13.99) & $14.78(13.85)$ & $19.17(20.74)$ & $<0.001^{*}$ \\
\hline Length of ICU stay, days (mean (SD)) & $2.59(6.59)$ & $4.57(9.61)$ & $5.72(9.38)$ & $<0.001^{*}$ \\
\hline Surgical site infection, $\mathrm{n}(\%)$ & $19(3.5)$ & $19(6.6)$ & $26(7.0)$ & $0.033^{*}$ \\
\hline Anastomosis leakage, $n(\%)$ & $7(1.3)$ & $4(1.4)$ & $10(2.7)$ & 0.299 \\
\hline Pulmonary complications, $\mathrm{n}(\%)$ & $20(3.7)$ & $21(7.3)$ & $43(11.7)$ & $<0.001^{*}$ \\
\hline Overall complications, $\mathrm{n}(\%)$ & $39(7.3)$ & $35(12.2)$ & $64(17.3)$ & $<0.001^{*}$ \\
\hline Mortality, n (\%) & $20(3.7)$ & $26(9.1)$ & 55 (14.9) & $<0.001^{*}$ \\
\hline
\end{tabular}

SD, standard deviation; HU, Hounsfield unit; PMA, psoas muscle area; SMA, skeletal muscle area; DMA, dorsal muscle group area; PMAD, psoas muscle area-density; SMAD, skeletal muscle area-density, DMAD, dorsal muscle group area-density

Table 4. Multivariate analysis of risk factors for complications and mortality among elderly patients presenting with abdominal emergencies 


\begin{tabular}{|c|c|c|c|c|c|}
\hline & & \multicolumn{2}{|l|}{ Complication } & \multicolumn{2}{|l|}{ Mortality } \\
\hline & & OR $(95 \% \mathrm{Cl})$ & $p$ value & OR $(95 \% \mathrm{Cl})$ & $p$ value \\
\hline Age (per year) & & $1.02(0.99-1.05)$ & 0.201 & $1.05(1.01-1.08)$ & $0.006^{*}$ \\
\hline \multirow[t]{2}{*}{ Sex } & female & 1 & & 1 & \\
\hline & male & $1.08(0.72-1.61)$ & 0.715 & $0.81(0.50-1.32)$ & 0.402 \\
\hline $\mathrm{BMI}($ per kg/m²) & & $1.03(0.98-1.09)$ & 0.226 & $1.02(0.96-1.09)$ & 0.501 \\
\hline \multirow[t]{2}{*}{ Hemodynamics } & stable & 1 & & 1 & \\
\hline & unstable & $0.95(0.47-1.81)$ & 0.874 & $1.81(0.88-3.58)$ & 0.095 \\
\hline \multirow[t]{2}{*}{ Surgical procedure } & Laparoscopy & 1 & & 1 & \\
\hline & Laparotomy & $3.13(1.67-6.25)$ & $0.001 *$ & $3.13(1.37-8.33)$ & $0.011^{*}$ \\
\hline \multicolumn{6}{|l|}{$\underline{\text { Comorbidities }}$} \\
\hline Diabetes mellitus & yes/no & $0.87(0.54-1.36)$ & 0.544 & $1.01(0.58-1.75)$ & 0.959 \\
\hline Hypertension & yes/no & $1.01(0.67-1.54)$ & 0.952 & $0.90(0.53-1.52)$ & 0.697 \\
\hline COPD & yes/no & $2.10(0.92-4.53)$ & 0.066 & $0.82(0.22-2.42)$ & 0.737 \\
\hline Cirrhosis & yes/no & $1.77(0.62-4.34)$ & 0.245 & $12.46(5.01-30.65)$ & $<0.001^{*}$ \\
\hline ESRD & yes/no & $1.42(0.62-3.06)$ & 0.393 & $1.52(0.61-3.58)$ & 0.356 \\
\hline CAD & yes/no & $1.40(0.64-2.86)$ & 0.372 & $0.99(0.34-2.51)$ & 0.987 \\
\hline CVA & yes/no & $3.03(1.82-4.97)$ & $<0.001 *$ & $2.83(1.51-5.17)$ & $0.001 *$ \\
\hline Cancer & yes/no & $1.20(0.73-1.94)$ & 0.459 & $1.51(0.85-2.62)$ & 0.146 \\
\hline \multicolumn{6}{|l|}{ Diagnosis } \\
\hline \multicolumn{2}{|l|}{ Appendicitis } & 1 & & 1 & \\
\hline \multicolumn{2}{|l|}{ Biliary disease } & $1.45(0.62-3.59)$ & 0.402 & $1.58(0.45-6.36)$ & 0.488 \\
\hline \multicolumn{2}{|c|}{ Hollow organ perforation } & $2.27(1.07-5.29)$ & $0.043^{*}$ & $3.10(1.10-11.2)$ & 0.051 \\
\hline \multicolumn{2}{|c|}{ Intestinal obstruction } & $1.62(0.73-3.90)$ & 0.251 & $2.23(0.75-8.35)$ & 0.184 \\
\hline \multicolumn{2}{|l|}{ Mesenteric ischemia } & $3.45(1.42-8.87)$ & $0.007 *$ & $13.12(4.39-49.61)$ & $<0.001^{*}$ \\
\hline \multicolumn{2}{|l|}{ Others } & $1.28(0.53-3.23)$ & 0.594 & $0.98(0.26-4.12)$ & 0.981 \\
\hline \multirow[t]{3}{*}{ PMG L4 } & normal & 1 & & 1 & \\
\hline & low & $1.57(0.93-2.65)$ & 0.087 & $2.24(1.14-4.49)$ & $0.021^{*}$ \\
\hline & very low & $2.11(1.32-3.42)$ & $0.002^{*}$ & $3.41(1.84-6.53)$ & $<0.001^{*}$ \\
\hline
\end{tabular}

Abbreviation: $\mathrm{Cl}$, confidence interval; OR, odds ratio; BMI, body mass index; COPD, chronic obstructive pulmonary disease; ESRD, endstage renal disease; CAD, coronary artery disease; CVA, cerebrovascular accident; PMI, psoas muscle index; SMI, skeletal muscle index; DMI, dorsal muscle group index; PMG, psoas muscle gauge; SMG, skeletal muscle gauge, DMG, dorsal muscle group gauge.

*statistically significant

\section{Figures}



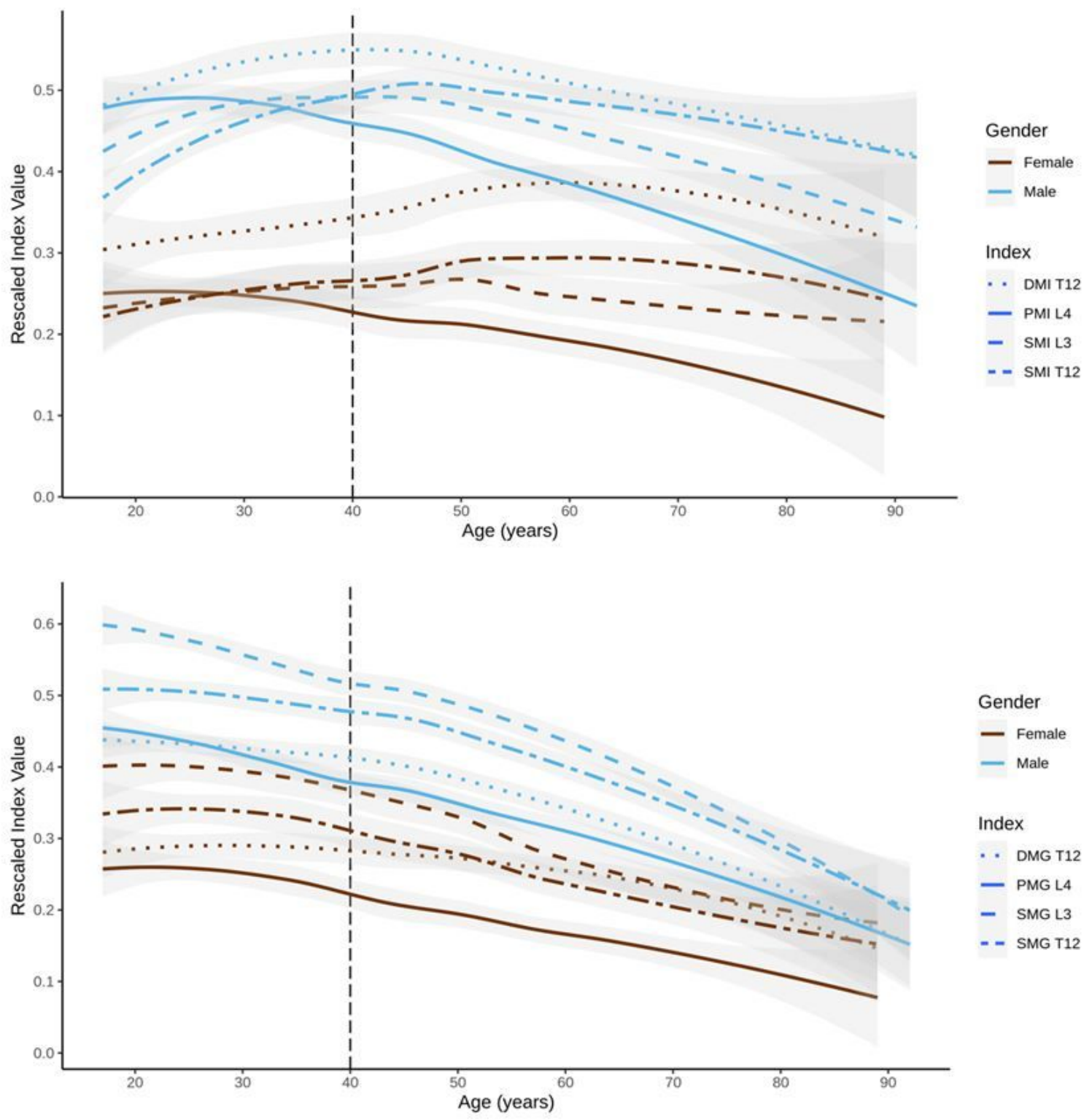

\section{Figure 1}

(A) The LOESS curve showed a correlation between each muscle index and age. (B) The LOESS curve showed a correlation between each muscle gauge and age. The indices were rescaled to a range of 0-1 to show the trend. Abbreviation: LOESS, locally weighted scatterplot smoothing; PMI, psoas muscle index; SMI, skeletal muscle index; DMI, dorsal muscle group index; PMG, psoas muscle gauge; SMG, skeletal muscle gauge, DMG, dorsal muscle group gauge.

\section{Supplementary Files}

This is a list of supplementary files associated with this preprint. Click to download.

- 4.SupplementaryMaterials.docx 